\title{
Article 177 of the Rome Treaty \\ as a Federalizing Device
}

\author{
Richard M. Buxbaum*
}

Hopes for development of a United States of Europe were an important reason for the flood of writings in the decade beginning in the mid-fifties that described, analyzed, praised, and extrapolated from the institutions establishing the three European Communities. The institutions that bore the greatest potential for federalizing the national governmental structures were the favored objects of study, and none was more intriguing than article I77 of the Treaty Establishing the European Economic Community (the Rome Treaty). ${ }^{2}$ Article I77 permits, and in some instances requires, national courts to certify to the Court of Justice of the Communities questions involving the validity or interpretation of acts of Community institutions that arise in the course of pending litigation. Other articles of the treaty give the Court jurisdiction over attacks on Community acts or failures to act by member states or other affected Community organs; ${ }^{2}$ and this remedy, on stated grounds, was even extended to private parties affected by the decisions of Community institutions. ${ }^{3}$ These important provisions open federal judicial channels, yet they contain significant limitations. A private litigant must show that a Community agency has acted against him directly, though a state may challenge regulations of general effect, even when it is not directly affected. Article $I 77$, on the other hand, may come into play any time

- A.B. I950, LI.B. 1952, Cornell University; LL.M. I953, University of California, Berkeley. Professor of Law, University of California, Berkeley. I am indebted to Mr. Gerd Müller for his research assistance and to the Institute of International Studies, Berkeley, for financial support.

I. Treaty Establishing the European Economic Community, done Mar. 25, r957, art. I77, 298 U.N.T.S. II [hereinafter cited as Rome Treaty].

Article 177 provides: cerning:-

"The Court of Justice shall be competent to give preliminary rulings (à titre préjudiciel) con-

"(a) the interpretation of this Treaty;

"(b) the validity and interpretation of acts of the institutions of the Community;

"(c) the interpretation of the statutes of any bodies set up by a formal measure of the Council, where the said statutes so provide.

"Where any such question is raised before any court of law of one of the Member States, the said court may, if it considers that a decision on the question is essential to enable it to render judgment, request the Court of Justice to give a ruling thereon.

"Where any such question is raised in a case pending before a domestic court of a Member State, from whose decisions there is no possibility of appeal under domestic law, the said court is bound to refer the matter to the Court of Justice." I CCH CoMm. Mrr. REP. \4655.

2. Rome Treaty, arts. $x 70,173,175$.

3. Rome Treaty, arts. 173, I75. See generally G. BeBR, JUdicial CoNTroL OF the EUROPEAN Connrunities (1962); Stein \& Hay, New Legal Remedies of Enterprises: A Survey, in I AMERICAN Enterprise in the European Common Market: A Legal Profile 459 (E. Stein \& T. Nicholson eds. Ig60). 
a lawsuit tangentially involves any economic area in which the Community acts or may act. Technically, in the role it provides for the originally seized court, the article sets up a procedure resembling the certification of questions for appeal in our federal system, ${ }^{4}$ or the granting of a certificate of importance to permit appeal that is found in some state codes. ${ }^{5}$ In a substantive and admittedly loose sense, it creates a kind of federal-question jurisdiction for the Court of Justice; in contrast, articles I73 and I75 merely provide for limited appeal from the actions of Community agencies.

This Article is a status report on the use of the certified-question device by the national courts of the member states. ${ }^{6}$ It is not, except incidentally, a study of the legal problems inherent in the provision. There are many studies of the latter variety, ${ }^{7}$ but little research has been done on the effectiveness of article $\mathrm{x} 77$, on the factors that have influenced that effectiveness, on

4. See 28 U.S.C. $\$ \$ 1254,1255(1964)$. For a discussion of the development and scope of the certification device see $R$. ROBERTSON \& F. KIRKHAM, JURISDICTION OF THE SUPREME COURT OF THE UNITED STATES 243-97 (2d ed. R. Wolfson \& P. Kurland I95I).

5. See, e.g., I IOA Ill. AnN. Stat. $\$ 316$ (Smith-Hurd ig68); N.Y. Const. art. 6, $\$ 3$ (b) (6) (McKinney Supp. 1968).

6. Some pre-I964 cases are included, but a fuller scarch was made for only the past 5 years. An apparently complete repository of case citations may be found in the serial publication of the Legal Service of the Commission of the European Communities entitled Decisions Nationales Relatives azt Droit Communautaire.

Although article $4 \mathrm{I}$ of the Treaty Instituting the European Coal and Steel Community, done Apr. I8, I95x, 261 U.N.T.S. I 40, contains a similar provision, the different structure of the interests affected by that treaty, its judicial and institutional setting, see Buergenthal, The Private Appeal Against Illegal State Activities in the Eutropean Coal and Steel Community, in AMs. J. Cosp. L. 325 (1962), and the scarcity of national decisions lead me to ignore its role and to concentrate on the Rome Treaty. For a full discussion of the federal judiciary under the Coal and Steel Treaty see S. Scheincold, THE Rule of Law in European Integration (1965). See also Lenhof, Jurisdictional Relationship Between the Court of the European Communities and the Courts of the Member States, 12 BuFF. L. REv. 296 (I963). For an economic discussion see E. Vollmer, Die wiRTsChaftLiche Bedeutung der RECHTSPRECHONG ZUM MONTANVERTRAG (x967).

Similarly, article I50 of the Treaty Establishing the European Atomic Energy Community, done Mar. 25, 1957,298 U.N.T.S. I67, is ignored here.

The recent fusion of the Executives of the three Communities, see Treaty Establishing a Single Council and a Single Commission of the European Communities, reprinted in 4 INT't LEg. MATERIALs 776 (1965), has not yet resulted in a fusion of the relevant complaint and appeal channels available under the separate treaties to the common Court of Justice of the European Communities. See Weil, Merger of the Institutions of the European Communities, 6I AM. J. INT'L L. 57 (1967). For an important statement on the chances of substantive and administrative integration see Hellwig, Das WVettbewerbsrecht bei der Fusion der drei Verträge, in BeITRÄGE ZUM EWG-KARTELLRECHT 211 (1967).

7. English language studies include G. BeBR, stipra note 3; P. HAY, FeDERALISM and Supranational Organizattons io2ff (I966); I D. Valentine, The Court of Justice of the European CoMMunities 303-10 (1965); E. Wale, The Court of Justice of the European CoMnunities 130-40 (1966); Berrios Martinez, The Nature and Function of Article 177 of the Rome Treaty, $5 \mathrm{~J}$. Comm. Mxт. ST. II3 (1966); Buxbaum, Incomplete Federalism: Jurisdiction Over Antitrtest Matters in the European Economic Commutnity, 52 CaLIF. L. REv. 56, 74-89 (x964); Feld, The European Community Court: Its Role in the Federalizing Process, 50 MinN. L. REv. 423, 432-38 (r966); Hay, Federal Jurisdiction of the Common Market Court, I2 Axr. J. Comp. L. 21, 30-35 (I963); Irelan, The European Court of Justice and the Struggle for Integration, 6 VA. J. INT'L I. II4 (I965); Lenhoff, stupra note 6, at 320-26; Mashaw, Federal Issues in and About the Jurisdiction of the Court of Justice of the European Communities, 40 TuL. L. REv. 21, 32-56 (1965); Opsahl, National Courts and the Community Court Under Article i77 of the EEC Treaty, in LEGAI ESSAYS-FESTSRRIFT TIL FREDE CAST-

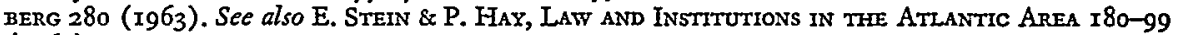
(1967).

Comprehensive studies in other languages are many. First should be mentioned C. Tonuschat, DIE GERICHILICHE VORABENTSCHEIDUNG NACH DEN VERTRÄGEN ÜBER DIE EUROPÄISCHEN GEMEINSCHAFTEN ( 1964$)$. Substantial discussions appearing since then include J. HeLLNER, DAS VorLAGEver- 
possible improvements in the law, or on the lessons the Community's experience provides for similar efforts to insinuate a federal judicial institution into a regional economic or political association.

The data can be viewed from a variety of perspectives or classifying approaches, such as subject matter, national origin, form of litigation, and type of certifying court. One test, however, should precede all efforts at classification: When was article I77 not applied when it could have been? This type of negative proof is difficult, not only because of the problems of search, but also because a subjective determination must be made in each case whether referral could reasonably have been expected. A factual review of each such case would unduly extend this paper, yet some proof must be presented to justify the conclusion that in any given case a reasonable certification was rejected or ignored. That it is an important part of the inquiry in assessing the effectiveness of article $I_{77}$ or similar provisions seems clear. $^{8}$

\section{The Certified Question in Appeals from Administrattve Actions}

The pathbreakers in developing the certification device were the Dutch courts, which began in the early I960's to submit to the Court of Justice the basic interpretation problem-whether the more commonly invoked treaty

FarRen der Europäischen Gemeinschaften (Diss. 1965); 3 R. Quadri, R. Monaco \& A. Trabucchi, Institutrvo Delia Comunftì Economica Europea-Commentario I3 io (I965); R. Socini, La competenza pRegiudriale della Corte di Giustizia delle Comunita europee (1967); E. STEINDORFF, RECHTSSCHUTZ UND VERFAHREN IM RECHT DER EUROPÄISCHEN GEMEINSCHAFTEN 66-97 (I964); and the more general surveys of N. Catalano, ManuEl DE droit des Communautís Européennes (2d. xg65); A. Donner, R. Chevallier, S. Neri, M. Waelbroek, K. Wolf \& L. BrinkHoRst, LE TUGE NATIONAL ET IE DROIT CONMUNAUTAIRE (I966). Of the periodical and essay literature see particularly Alexander, Questions préjudicielles: L'application recente de l'article I77 CEE par la cour de justice et par les jurisdictions nationales, 1965 CAHIERS DE DRorr EuropéEN [hereinafter cited as Camiers] 47; Constantinesco, Zur Vorlage nationaler Instanzgerichte an den Europäischen Gerichtshof, 13 AussenWIRTSCHAFTsDIENST DES BETRIEBs-Beraters [hereinafter cited as AWD] I25 (1967); Daig, Aktuelle Fragen der Vorabentscheidungen Nach Art. I77 EW G-Vertrag Unter Besonderer Beriüchsichtigung von Rechtsprechung und Praxis des Gerichtshofes der Europäischen Gemeinschaften, 3 Europarecrt 259, $37 \mathrm{x}$ (I968); Dumon, Le Renvoi Préjudiciel, in Droit CommunauTAIRE ET DROIT NATIONAL 197 (1965); Ehle, Interdependenz zwischen Gemeinschaftsordnung und nationaler Rechtsordnung, I 8 NEUE JURISTISCHE WocHENscHRIFT [hereinafter cited as NJW] $223 \mathrm{I}$ (1965); Jeantet, Chronique de Droit Economique Européen, 38 La Semanne Juridroue I, No. I812 (1964); Juillard, Procédure des questions préjudicielles et renforcement du lien communautaire, 4 REVUE TRMIESTRIELlE DE DRoIT EUROPEEN [hereinafter cited as REV. DR. EuR.] 293 (I968); Knopp, Über die Aufgabenteilung zwischen dem europäischen Gerichtshof und den nationalen Gerichten bei der Auslegung des Gemeinschaftsrechts, in FEsTschirIFT Für PHILIPP MöHRING 449 (1965); Lauwaars, De Bevoegdheden Van Het Hof Van Justitie Krachtens Een Toekomstig Verdrag Tot Oprichting Van Een Europese Gemeenschap, 16 SocIAAL-EcoNomische WETGEviNg [hereinafter cited as S.E.W.] 350, 388-404 (I968); Mertens De Wilmars, La procédure suivant l'article I77 C.E.E., I3 S.E.W. 437 (1965); Pepy, Les questions préjudicielles dans les traités de Paris et de Rome et la jutrisprudence de la cour de justice des communautés européenes, I965. Carmers I94; Pepy, Le role des jurisdictions nationales dans l'application de l'article $I 77$ et la jurisprudence de la cour de justice, I966 Camiers 21, 459; Selmer, Zur Entscheidungserheblichkeit der Gültigkeitsfrage bei der Vorlage nach Artikel 177 des EWG-Vertrages, I4 AWD 424 (1966); Ule, Der Europäische Gerichtshof und die deutsche Verwaltungsgerichtsbarkeit, 82 DeuTsches VerwaltungsBLATT I (I967).

For further citations see the voluminous references in the national reports of Union Internationale Des Avocats, La Procédure selon l'article 177 du Traité instituant la Communauté Économique Européenne, $1_{3}$ S.E.W. $385,388,435-36,467-70,503-05$ (1965).

8. See Daig, supra note 7 , at 289 , calling for such inquiry. 
provisions were programmatic only, requiring national legislative or administrative implementation, or whether they directly established private rights in the face of conflicting national provisions. ${ }^{9}$ It was not until the basic van Gend \& Loos case ${ }^{10}$ was assimilated by national authorities-perhaps not until the Costa-E.N.E.L. decision of $1964^{11}$ - that the role of the Court of Justice in treaty interpretation was confirmed and the task begun of deciding whether particular national statutes and regulations were compatible with the relevant treaty provisions. This task has involved three basic groups of state programs now within the competence of the Community: social security for migrant workers; quasi-tariff tolls, levies, and taxes; and protectionism for state enterprises.

These programs are listed in increasing order of political sensitivity. Reluctance or readiness to certify questions of administrative law, however, displays definite national patterns, even after accounting for variations in the intensity or political delicacy of the subject at issue. Only social security problems have been certified consistently. ${ }^{12}$ Even in the relatively neutral field of tariff-related taxes-where the issue is the compatibility of a national levy with treaty provisions prohibiting increased tariffs or tariff-like leviesquestions commonly referred to the Court of Justice by Dutch ${ }^{13}$ and now even German ${ }^{24}$ courts are routinely ignored or affirmatively kept out of

9. See, e.g., Société Kledingverkoopbedrijf de Geus v. Société de Droit Allemand Robert Bosch $\mathrm{GmbH}, 8$ Recueil de la Jurisprudence de la Cour de Justice des Communautés Européennes [hereinafter cited as Rec. Jur.] 89, English translation in I Comm. Mkt. L.R. I (I962); review of this debate in Buxbaum, Antitrust Regulation Within the European Economic Community, 6I Coruns. L. REv. 402, 417-20 (196r). Hereafter the fact that the decisions appearing in the Common Market Law Reports are translations will not be stated.

Io. N.V. Algemene Transport- en Expeditie Onderneming van Gend \& Loos v. Administration Fiscale Néerlandaise, 9 Rec. Jur. I, 2 Comm. Mkt. L.R. I05 (1963); see Riesenfeld \& Buxbaum, N.V. Algemene Transport-En Expeditie Onderneming Van Gend \& Loos c. Administration Fiscale Néerlandaise: A Pioneering Decision of the Court of Justice of the European Communities, 58 Ax. J. INT'L L. I52 (rg64).

II. Costa v. E.N.E.L., Io Rec. Jur. II4r, 3 Comm. Mkt. L.R. 425 (I964); see Stein, Toward Supremacy of Treaty-Constitution by Judicial Fiat: On the Margin of the Costa Case, 63 MrcH. L. REV. 49I (I965).

12. In lieu of individual citations to the scores of cases see Lyon-Caen, La jurisprudence sociale de la Cour de justice, 4 REv. DR. Eur. I48 (I968), as well as the same author's series of commentaries, Droit social européen, in I REv. Dr. EUR. 84, 425 (I965), 2 Rev. Dr. EuR. 32I (I966), and 3 REV. Dr. Eur. 868 (I967). For more general discussions see M. FItzGERAID, ThE Commron MARRET's LabOR Programs I27-49 (1966); Maas, The Administrative Commission for the Social Security of Migrant Workers, 4 CoMm. MrT. L. Rev. 5I (1966); Séché, Bilan de la jurispradence de la Cour de Justice des Communautés Européennes relative aux règlements nos 3 et 4 concernant la sécurité sociale des travailleurs migrants, 4 REv. Dr. Eur. 475 (1968).

I3. See, e.g., the decisions of the Court of Justice, rendered upon the request of Dutch courts, in N.V. Algemene Transport- en Expeditie Onderneming van Gend \& Loos v. Administration Fiscale Néerlandaise, 9 Rec. Jur. I, 2 Comm. Mkt. L.R. I05 (I963); N.V. Internationale Crediet- en Handelsvereniging «Rotterdam» v. Ministre de l'Agriculture et de la Pêche, to Rec. Jur. I (I964); Da Costa en Schaake N.V. v. Administration Fiscale Néerlandaise, 9 Rec. Jur. 59, 2 Comm. Mkt. L.R. 224 (1963).

I4. See, e.g., the decisions of the Court of Justice, rendered upon the request of a Greman court, in Waldemar Deutschmann v, République Fédérale de l'Allemagne, II Rec. Jur. 6or, 4 Comm. Mkt L.R. 259 ( 1965 ), and Firma Molkerei-Zentrale Westfalen/Lippe GmbH v. Hauptzollant Paderborn, I4 Rec. Jur. 2II (r968); and the certification of the Finanzgericht Saarland, reported in Agence Internationale dTnformation pour la Presse, No. 227 (n.s.), Dec. 4, 1968, at ro. 
that process by the French courts. ${ }^{15}$ This phenomenon is not limited to the Conseil d'Etat and the inferior administrative tribunals, in which a certain command influence based upon staffing traditions might. perhaps be expected, ${ }^{16}$ but is also found in the civil courts, including both chambers of the Cour de Cassation. ${ }^{17}$

The more political and sensitive the issue, the more marked the divergence. One of the more flagrant instances concerns the refusal of French courts to subject their national regulatory scheme for oil importation and distribution to the test of compatibility with treaty provisions. ${ }^{18}$ Faced with a procedural format that precluded resort to the doctrine that local law rather than treaty interpretation was at issue, ${ }^{19}$ the French courts resorted to an equally dubious but more traditional doctrine dispensing with such interpretive requests when the treaty provision involved was an "acte clair" permitting of only one interpretation. ${ }^{20}$ An Italian court, faced with the

15. See citations in notes $18-20$ infra.

16. See R. David, Le droit frangais 365-84 (1960); P. Herzog, Civin Procedure in France $\mathrm{IX}_{4}$ (I968); Guillen, Les commissaires du governement près les jurisdictions administratives et, spécialement, près le Conseil d'État français, 7 I REvuE DU Drort PuBLIC 28I (1955); Riesenfeld, The French System of Administrative Justice: A Model for American Law?, I8 Boston U.L. REv. 48,400 , 715 , especially 52-82, 715-23,743-48 (1938). The recent institutional changes of the Conseil d'Etat, Decree of Sept. 9, I968, [1968] J.O. : 769, [r968] D.S.L. 272, are here irrelevant.

17. See citations in notes I 8-20 infra. This reluctance has become a political issue. See, e.g., the parliamentary question and Commission response at xO $\mathrm{J}$. OFFICIEL DES COMMUNAUTÉs EUROPÉENNES [hereinafter cited as E.E.C. J.O.] No. 270/2-3, Nov. 8, 1967.

18. Re Société des Pétroles Shell-Berre, 84:2 Gazette du Palais [hereinafter cited as Gaz. Pal.] 35 (Conseil d'État), 3 Comm. Mkt. L.R. 462 (1964).

19. See, e.g., the use of this rubric in Re Riff, $84: 2$ Gaz. Pal. 42 (Cass. crim. 1964), 4 Comm. Mkt. L.R. 29; Etat Français v. Nicolas, 83:1 Gaz. Pal. 426 (Cour d'appel, Amiens r963), 2 Comm. Mkt. L.R. 239; Corn \& Food Trading Co. v. Etat belge, 83 Journal des Tribunaux [hereinafter cited as J.T.] 98 (Tribunal Civil, Bruxelles r966), 5 Comm. Mrt. L. Rev. 326 (I967).

That the Court of Justice does not enjoy the power to rule on the validity of municipal law is a self-evident, yet necessary, statement. See Schlochauer, Der Gerichtshof der Europäischen Gemeinschaften als Integrationsfaktor, in PROBLEME DEs EUROPÄISCHEN RECHTS, FESTSCHRIFT FÜr WALTER HaLLSTEIN 43I, 443-44 (1966). The Court of Justice does enjoy the power to interpret treaty norms and thus to indicate the lack of conformity of a particular municipal rule therewith. See Lenhoff, supra note 6, at 297-98; Riesenfeld \& Buxbaum, supra note 10, at 156-57; Schlochauer, supra. But see Ule, supra note 7 , at 10.

This problem is related to the distinction between abstract interpretation of a treaty norm and its application to a specific problem being litigated in the certifying court. Here, too, distinctions are more formal than real. See Buxbaum, supra note 7, at 74; Nicolaysen, Comment, 2 EUroparecht 146 (1967); Ryziger, Comment, I965 CaHIERS 255.

And in turn these problems are related to the question of the relation between the certification procedure and the ability of the affected party to challenge the legality of a municipal or even a Community "regulation" (in this context not a term of art) in the absence of standing to challenge it directly. See Geisseler, Empfiehlt es sich, Bestimmungen ïber den Rechtsschutz zu ädern?, in ZEHN

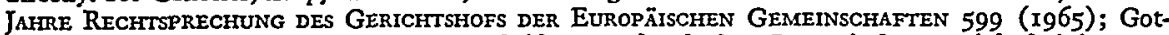
schlich, Nachprüfbarkeit von EW G-Entscheidungen durch den Europäischen Gerichtshof im Verfahren der Vorabentscheidung, Io AWD 43 (1964); Jeantet, supra note 7; Schibel, Comment, 10 AWD 88 (1964).

20. The court decided that the Treaty provision in question "clearly" was not intended to apply directly in such disputes. See Re Société des Pétroles Shell-Berre, 84:2 Gaz. Pal. 35 (Conseil d'État 1964), 3 Comm. Mkt. L.R. 462. See also Société des Établissements Petitjean, [1967] Recueil des Decisions Du Conseil d'ttat 63; Lapeyre v. Administration des Douanes, 6 Comm. Mkt. L.R. 362 (Cass. crim. I967).

For a typical reaction see the exchange between a member of the European Parliament and the Commission, reprinted in H. Steiner \& D. Vagts, Transnational. Legal Problems i 88 (ig68). 
same issues, called for certification without ado. ${ }^{21}$ Undoubtedly the theory of the "acte clair" is useful, especially once the fullness of time has embedded some of these rather general treaty norms in an ample sediment of case law $;^{22}$ but its use and recurrent misuse ${ }^{23}$ at this stage of Community development is a sign of resistance. This attitude has for now culminated in the recent decision of the Conseil d'Etat holding that regulation rg of the Council of Ministers of the Economic Community, which forbids certain domestic preferences in the cereals sector, was superseded in France by the laterenacted law governing tariff preferences for Algerian wheat. ${ }^{24} \mathrm{~A}$ request for a Court of Justice ruling might well have led to a similar result, given the circumstances of Algeria's departure from metropolitan status, but no such request was even considered. The case has occasioned comments of the sort usually associated with spurned lovers, ${ }^{25}$ but it is only a logical and expectable extension of the long-standing French position.

The German situation is more mixed. Following an initial reluctance ${ }^{28}$ to accept the "direct applicability" concept that is so enthusiastically promoted by the Court of Justice, the past few years have witnessed an increasing tendency to accept the certification procedure in most of the relevant administrative-law fields. Indeed, I 968 saw a spate of such cases, the most important involving the legitimacy of the new turnover equalization-tax regime $;^{27}$ and this despite the overstated warning that the administrative courts were in danger of drowning in the flood of tax appeals raising this

21. Société Albatros v. SOPECO, [1964] Foro Ital. I. I088, [I964] Giur. Petrol. 276 (Tribunale di Roma), 2 CoMm. MKT. L. REv. 220 (I964).

22. This expectation is reflected in the holding of the Court of Justice extending the national courts' duty of certification only to those matters not already the subject of the Court's rulings. Da Costa en Schaake N.V. v. Administration Fiscale Néerlandaise, 9 Rec. Jur. 59, 2 Comm. Mkt. L.R. 224 (1963); see Robert, Comment, [1963] D. Jur. 642.

On the doctrine of the "acte clair" see Chevallier, Note, 3 Comam. MKr. L. Rev. Ioo (Ig65); Daig, supra note 7, at 285-89; Dumon, supra note 7, at 236-40; Fourré \& Wenner, Der EW G-Vertrag in der Gerichtspraxis (Artikel 37 und 177), II AWD I49 (1965); Pepy, Le role des jurisdictions nationales dans l'application de l'article 177 et la jurisprudence de la cour de justice, I966 CAHIERs 2I, 34ff; Schober, Die Lehre vom 'Acte Clair' im französischen Recht, I9 NJW 2252 (Ig66); Wenner, Entscheidung des französischen Conseil d'Etat zu Artikel 177 des EWG-Vertrages, Io AWD 26I (1964).

For the proposition that need for a "federal" definition of apparently clear legal and factual terms may often dictate recourse to article I 77 see Ehle, supra note 7 , at $223 \mathrm{I}$.

23. See the decisions of the Conseil d'Etat discussed and criticized in Tallon \& Kovar, The Application of Community Law in France in 1967,5 CoMM. MKT. L. REv. 488 (1968).

24. Syndicat général de fabricants de semoules de France, [1968] D.S. Jur. 285 (Conseil d'État). Particularly interesting is the review and rejection of an article 177 certification by the Commissaire du Gouvernement, reprinted in 57 REVUE CRITIQUE DE DROIT INTERNATIONAL PRIVE 5 I6 (I968).

25. See Constantinesco, Comment, 3 Europarecht 3I8 (I968); Ipsen, Comment, 3 EuropaRECHT 330 (Ig68). Local comment was equally sharp. See M.L. [Lagrange], Note, [I968] D.S. Jur. 286; Kovar, Note, 57 ReVUE CRITIQUE DE DROIT INTERNatTonal PRIVE 527 (I968); ConstantinidesMégret, Note, 4 Rev. Dr. Eur. 396 (I968).

26. See, e.g., the rejection of certification in Judgment of June $15, x 966,42$ Zeitschrift für Zölle und Verbrauchssteuern 286 (Verwaltungsgericht Frankfurt); Judgment of May 24, 1966, 14 Entscheidungen der Finanzgerichte [hereinafter cited as FinG] 537 (Finanzgericht Berlin), 6 Comm. Mkt. L.R. 340; Judgment of Aug. 4, I965, I3 FinG 592 (Finanzgericht Hamburg), 5 Comm. Mkt. L.R. 409.

27. In lieu of the case citations see Meier, Die April-Urteile des Eutropäischen Gerichtshofes im

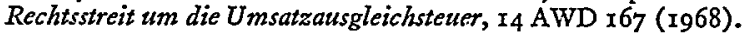


question. In a sense, the determined effort to resolve these various questions of compatibility at once through a set of references to the Court of Justice probably cleared the scene by eliciting the expected rulings of legitimacy from the Court. ${ }^{28}$

\section{Certifications in Litigation Between Private Parties}

The most important Community subject matter involved in private litigation has been antitrust law. Its quantitative importance need hardly be stressed. ${ }^{29}$ As a result, the impact of community attitudes on the national courts, and consequently the chance for the development of a "federal judiciary," can best be measured in the field of antitrust law. In a subtler way, antitrust cases test the impact of a particular substantive Community legal regime upon national courts and thus upon national law. With few exceptions, the subjects at issue in the administrative proceedings discussed above do not directly impinge upon judicial lawmaking at the national level. There is no particular lawmaking significance-political issues such as a local court's eccentric challenge to the entire treaty structure aside-in sending a question of the compatibility of a national tariff regulation or even turnover-tax law to the Court of Justice. The role of the national courts in reviewing these regulations and laws is not so essentially a normparticularizing one as when they give flesh and substance to the general concepts of "unfair competition" or "restraint of trade." In the former fields, as the French experience demonstrates, an essentially political attitude may well prevail, and national variations in receptiveness to a supranational judiciary may be correspondingly significant. Nevertheless, the creative function of the judiciary, its common law role, is not involved in any significant way. If one seeks to discover whether this common law role engenders its own functional attitudes, the antitrust cases provide a useful testing ground. Finally, these private litigation cases, along with administrative appeals, may yield insights into the relationship between such a certification procedure and the substantive development of the particular field at issue. Assuming for the purposes of the inquiry a value judgment in favor of fairly rigorous antitrust enforcement, I propose to examine the consequences to that policy of using or not using the article I77 procedure. Since the Court of Justice has decided only five cases in the antitrust field

28. See Firma Molkerei-Zentrale Westfalen/Lippe GmbH v. Hauptzollamt Paderborn, I4 Rec. Jur. 2 Ix (1968), and the further decisions of the Court dated Apr. 4, I968, I4 Rec. Jur. 26r, 275, $293,305,327,347,359$.

29. For a tangible illustration thereof see the table of citations to such cases, Verzeichnis bisher ergangener Entscheidungen zum EWG-Wettbewerbsrecht, in Deringer, Kommentar zum EWGWettbewerbsrecht, I8 WIRTSCHAFT uND WeTTBEWERB [hereinafter cited as WuW] I49-69 (I968). The reporter segment of WuW, "Entscheidungssammlung," which is consecutively paginated for each court, will be cited WuW plus judicial abbreviation. 
under this procedure, ${ }^{30}$ and only three others are presently pending, ${ }^{31}$ what will in fact be tested is the impact upon antitrust development of not using the preliminary question process.

In the typical private suit a party charged with unfair competition, breach of contract, or inducement to breach of contract because of a distribution practice conflicting with that used or imposed by the complainant counters with the argument that the contractual regime it is charged with violating is itself a violation of article 85 or 86 of the Rome Treaty. Obviously the most common example will be the claim by a nonsigning retailer that its sales of price-maintained goods below the resale price fixed by the manufacturer or a complaining distributor are immunized because the contractual resale price maintenance scheme is incompatible with these treaty provisions.

A nation-by-nation examination of the antitrust cases turns up an interesting mixture of attitudes. In France, where the most extreme opposition to supranational institutions has been vividly and politically displayed in the administrative decisions, ${ }^{32}$ the courts have rejected every effort but one of a litigating party to obtain an article $x 77$ certification. ${ }^{33}$ Several courts, however, have on their own interpreted article 85 of the treaty and the implementing regulation I7 so as to strengthen Brussels' hand. ${ }^{34}$ Regulation I7, which governs inter alia the distribution of competence between the EEC Commission and the national authorities, provides for a suspension of national proceedings once the Commission's Directorate General for Competition has itself initiated proceedings in the same matter. This requirement has been read by a few French courts, ${ }^{35}$ by no means the majority, as extending to proceedings pending before national courts as well as before

30. Farbenfabriken Bayer AG v. Bundeskartellamt, No. $14 / 68$, Feb. I3, I969 (mimeo.); Parke, Davis \& Co. v. Probel, I4 Rec. Jur. 8I, 7 Comm. Mkt. L.R. 47 (1968); S.A. Brasserie de Haecht v. Consorts Wilkin Janssen, $x_{3}$ Rec. Jur. 525, 7 Comm. Mkt. L.R. 26 (1967); Société Technique Minière v. Maschinenbau Ulm GmbH, I2 Rec. Jur. 337, 5 Comm. Mkt. I.R. 357 (Ig66); Société Kledingverkoopbedrijf de Geus v. Société de Droit Allemand Robert Bosch GmbH, 8 Rec. Jur. 89, I Comm. Mkt. L.R. I (rg62).

3r. Judgment by Gerechtshof Rotterdam, reported in Agence Internationale d'Information pour la Presse, No. 24I (n.s.), Dec. 23, I968, at 5; Judgment by Oberlandesgericht München, reported in id. at No. 277 (n.s.), Feb. 19 , 1969, at 5; Judgment by Tribunal de Commerce, Bruxelles, reported in id. at No. 288 (n.s.), Mar. 6, 1969, at 8 .

32. See note I2 supra and accompanying text.

33. The only certification in this field is that in S.A. La Technique Minière v. Société Maschinenbau UIm GmbH, 85:2 Gaz. Pal. (Jur.) 90 (Cour d'appel, Paris I965). For the proceeding before the European Court of Justice see note 30 supra.

34. Reg. No. I7 art. 9, 5 E.E.C. J.O. 204 (I962), reprinted in I CCH CoMm. MkT. Rep. I 240I, at I700. See, e.g., Cie. Française Telefunken S.A. v. Ets. Aubin, [1964] REvue InTERNATronale DE Drott de Concurrence [hereinafter cited as REv. INT. Conc.] No. 83, at 35 (Tribunal de Commerce, Marseille), 4 Comm. Mkt. L.R. I85; CNMB v. BMB, [1965] REv. INT. CoNC. No. 89, at 44 ('Tribunal de Commerce de la Seine).

For an explanation of the division of powers between national authorities and the Commission as established by this regulation see Buxbaum, supra note 7, at 59-67.

35. See, e.g., Société Union Nationale des Économies Familiales v. Et. Consten, 83:I Gaz. Pal. (Jur.) 157 (Cour d'appel, Paris 1963 ), rev'd, reported in Verzeichnis, supra note 29, at 164 (Cass. civ. 1965$)$. 
administrative authorities, a reading much disputed and still in some doubt. ${ }^{36}$ I read this paradoxical position as a reflection of the strong French stand against restrictive vertical distribution arrangements, which happen to be involved in almost all of these proceedings. Though increasingly riddled with exceptions, the French law expresses a traditional policy in favor of open distribution channels. ${ }^{37}$ As a result, those courts still sympathetic to open distribution may accept the suspensive effect of certification with equanimity, if indeed they do not actually seek out the certification procedure, in order to provide the maverick distributor with a maximum period of immunized operations; though the issue of the legality of the producer's distribution system under newer French developments may, depending upon the Commission's action, still have to be faced by them. Even this much conceded, however, it is important to note that the majority of French cases reported have rejected suspension as well as certification, ${ }^{38}$ and have thus protected "legitimate" distribution channels against such outsiders. This has occurred in situations that the still-developing French law now exempts from the statutory sanction, whether or not the still-developing Community law would do so. ${ }^{39}$

The one French decision resulting in a certified question ${ }^{40}$ arose under circumstances confirming this interpretation of the recent French attitude toward restrictive distribution practices. A German tractor producer had sold a number of tractors to a French company, pursuant to a contract appointing the latter its exclusive distributor in France and requiring it to refrain from dealing in competing machines. In defending against a suit for breach of contract, the French company claimed the illegality and thus nullity of the agreement under Community standards. Because the Commission had not been notified of the agreement within the period specified in article 5 of regulation $\mathrm{I} 7$, an article 85 (3) exemption was no longer available. Faced with the clear ruling of the Commission in the Grundig case $^{41}$ (then being appealed) that such agreements were ipso facto subject to article 85 (I) and could escape nullity only through an 85 (3) exemption, the French court certified two questions to the Court of Justice: First, it

36. See Buxbaum, supra note 7, at 6I-63; Deringer, Kommentar zu den EWG-Wettbewerbsregeln (Art. 85f) nebst Durchfiilurungs-Verordnungen und -Richtlinien, 13 WuW 364-66 (1963); Schlicder, Comment, 9 AWD 85 ( 1963$)$.

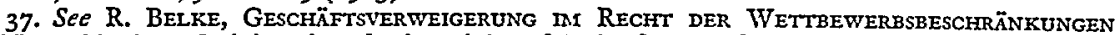
(1966); Goldstein, Administrative Shaping of French Refusal To Deal Legislation, II AM. J. CoMp. L. 515 (1962).

38. See cases cited in note 99 supra; Etat Française v. Nicolas, 83:I Gaz. Pal. 426 (Cour d'appel, Amiens), 2 Comm. Mkt. L.R. 239; Fédération Nationale des Cinémas Française v. Office de Radiodiffusion-Télévision Française, 85:I Gaz. Pal. (Jur.) 299 (Tribunal de Commerce de la Seine x965), ${ }_{4}$ Comm. Mkt. L.R. ror.

39. See, e.g., Laffont v. S.A. les Laboratoires Sarbach, 3 REv. DR. Eur. I44 (Cour d'appel, Paris 1967); S.A.R.L. Lavècire France v. Société belge Isobel, 83 J.T. 512 (I968) (Cour d'appel, Paris 1967).

40. See note 33 supra.

4r. Decision of Sept. 23, 1964, 7 E.E.C. J.O. 2545, 3 Comm. Mkt. L.R. 489. 
sought an interpretation of the substantive criteria of article 85(r) (essentially the main issue in Grundig); secondly and more significantly, it asked whether the nullity provision of article 85 (2) was intended to void the entire agreement containing the restrictive clause or only part of the agreement, as determined by the local law governing severability. The Court of Justice's response to these two questions, opting for the milder interpretation, ${ }^{42}$ enabled the French court, on remand, to uphold the complainant's right of action. ${ }^{43}$ This case, in short, suggests that the certified-question procedure might be used to promote and seek confirmation of a national antitrust policy, but not to provide an inroad for a new, or at least a more vigorous, Community antitrust policy not in harmony with national standards.

In the Netherlands, where if anything the opposite antitrust policy prevails as to problems of "orderly" distribution, and where outsiders' efforts to breach these channels are not favored, ${ }^{44}$ a conflict between the domestic policy and the equally fervent Dutch political position in favor of judicial integration at the Community level ${ }^{45}$ might well be expected. As it happens, the more recent of the two Dutch cases certifying questions to the Court of Justice involved industrial property rights; $;^{46}$ but more significantly, both certification decisions at the same time granted interim relief to the complaining party whose contract or infringement suit was counterattacked on article 85 grounds. Thus, Dutch adherence to federal principles has not been allowed to interfere with maintaining the domestic antitrust laws any more than necessary. Equally significant, of course, is the spotty record of even the Dutch courts on certification. Against these two cases must be balanced two refusals to certify by the Hoge Raad, the Dutch Supreme Court, which normally is obligated under article $I 77$ to invoke that procedure, once on the ground that the issue was raised too late ${ }^{47}$ and once, against the request of its own Advocate General, without any specification of reasons. ${ }^{48}$ Each case involved an issue similar to that finally brought to

42. Société Technique Minière v. Maschinenbau Ulm GmbH, 12 Rec. Jur. 337, 5 Comm. Mkt. L.R. 357 (I966).

43. Judgment of Feb. 22, 1967, 3 Rev. DR. EuR. I48 (Cour d'appel, Paris); compare Judgment of Dec. I 4, I967, 4 REv. DR. Eur. 375 (I968) (Oberlandesgericht München); Judgment of Feb. 23, 1967, [1968] Gewerblicher Rechtsshutz und Urheberrecht-Auslands-und Internationaler Teil [hereinafter cited as GRUR-AIT] 23 (Landgericht Hamburg).

44. See Riesenfeld, The Protection of Competition, in 2 American Enterprise in the Europenn CoMmon MARKET: A LEgaL Profile 197, 263-69 (E. Stein \& $T$. Nicholson eds. I960).

45. See, e.g., L. Erades \& W. Gould, The Relation Between InTERNational LaW and MONICIPAL LAW IN THE NETHERLANDS AND IN THE UNITED STATES (I96I).

46. In that order, they are Parke, Davis \& Co. v. Probel, I 4 Rec. Jur. 8r, 7 Comm. Mkt. L.R. 47 (1968), certified in Judgment of July 30, 1967, 15 S.E.W. 229 (Gerechtshof's Gravenhage 1967); Société Kledingverkoopbedrijf de Geus v. Société de Droit Allemand Robert Bosch GmbH, 8 Rec. Jur. 89, I Comm. Mkt. L.R. I (1962), certified in Judgment of June 30, 196r, [196r] Nederlandse Jurisprudentie [hereinafter cited as N.J.] 785 (Gerechtshof's Gravenhage).

47. Schetselaar v. Geigy A.G., [Ig66] N.J. 1156 (Hoge Raad), 4 Comm. Mkt. L.R. 47.

48. Constructa Werke GmbH v. De Geus en Uitdenbogerd N.V., [1964] N.J. II2I (Hoge Raad), 4 Comm. Mkt. L.R. I7. See also Petit \& Fritsen NV v. Nederlandse Klokkenspel-Vereniging, [I966] N.J. 442 (Hoge Raad). 
the Court of Justice in the Parke, Davis case, ${ }^{49}$ which, it should be recalled, came to that court not from the Hoge Raad but from a court of intermediate jurisdiction. ${ }^{50}$ That same intermediate court had twice earlier rejected pleas for certification in essentially identical situations; ${ }^{51}$ and so, at least four times, had courts of first instance. ${ }^{52}$ All in all, then, one can argue that any drive toward judicial integration has come off second best to the desire to maintain the existing substantive regime in this field of the law.

The Belgian situation is essentially similar. As of early Ig68 only one case had been certified to the Court of Justice, ${ }^{53}$ again protecting the challenged exclusive distributorship against the pirating distributor through interim enforcement of Belgian law. Further, in at least nine cases decided since $I 962$ the various courts involved withheld certification, more often without $^{54}$ but sometimes with ${ }^{55}$ explicit discussion of their reasons: in some instances on the basis of the asserted limit of the restrictive practice to "intrastate commerce," in others because of a dubious reading of the Court's early Bosch ${ }^{57}$ decision as validating agreements timely submitted to the Commission under the notification procedure of regulation $I 7 .{ }^{58}$ Others may have turned on whether article 85 extends to "foreign commerce," 59

49. See note 30 supra.

50. See note 46 supra.

51. Vyvyx N.V. v. C.H. Boehringer Sohn, [1967] N.J. xO2I (Gerechtshof's Gravenhage); Linde's Eismachinen A.G. v. V.O.F. De Geus en Uitdenbogerd, 9 S.E.W. 120 (Gerechtshof's Gravenhage 1961). See Vyvyx v. Geigy, 1967 Carners 708 (Gerechtshof's Gravenhage). See also Kadee v. Grundig (Nederland) N.V., [1964] N.J. 1230, 4 Comm. Mkt. L.R. 40 (Gerechtshof's Gravenhage 1963 ).

52. N.V. Eerste Nederlandse Lucifers Handelmaatschappij v. Dirk van der Broek's Supermarket N.V., [r967] N.J. 313 (Arrondissements-Rechtbank Amsterdam); Francesco v. Schetselaar, [1966] Bijblad bij de Industriele Eigendom 232 (Arrondissements-Rechtbank, Rotterdam); Merck \& Co. v. Vyvyx N.V., [1966] N.]. 124 (Arrondissements-Rechtbank, Rotterdam 1965); Biochemie GmbH v. Nogepha N.V., [1965] N.J. 27o (Arrondissements-Rechtbank, Amsterdam 1964), 4 Comm. Mkt. L.R. 248. See also I5 NeDERLands TijDschrift Voor InTERNationaAl ReChT 21 II (Ig68).

53. S.A. Brasserie de Haecht v. Consorts Wilkin Janssen, $x_{3}$ Rec. Jur. 525, 7 Comm. Mkt. L.R. 26 (I967), certified sub nom. Brasserie de Haacht, S.A. v. Wilkin, I967 Cakiers 549 (Tribunal de Commerce, Lì̀ge).

54. S.A. en liquidation «Carrières Dufour» v. S.A. en liquidation «Association générale des fabricants belges de ciment Portland artificiel», I968 Carmers 436 (Cass. I, 1967); Spierkel v. Agence et Méssageries de la Presse, S.A., 77 J.T. 459 (Cour d'Appel, Bruxelles I962), 3 Comm. Mkt. L.R. I 42; SPRL Ets. Erwin Brenneisen v. Hempel, 82 J.T. I19 (Tribunal de Commerce, Bruxelles 1966); Soc. dr. anglais Notek Electric Cy. v. Collignon, 82 J.T. 243 (Tribunal de première instance, Bruxelles 1966); N.V. Sieverding v. Vermeer-Thys, 29 Rechtskundig Weekblad [hereinafter cited as R.W.] col. 994 (Tribunal de première instance, Bruxelles 1966); N.V. Union de Remorquage et de Sauvetage v. N.V. Schelde Sleepvaartbedrijf, 28 R.W. col. 314 (Rechtbank van Koophandel, Antwerpen, 1964); ASPA v. Superbazars, 77 J.T. 298 (Tribunal de Commerce, Bruxelles 1962), 2 Comm. Mkt. L.R. 28.

55. Schott v. Remacle, $8 \mathrm{I}$ J.T. $67 \mathrm{I}$ (Cour d'Appel, Liège, I966); Blume v. Van Praag, 78 J.T. 733 (Rechtbank van Koophandel, Antwerpen I962), 2 Comm. Mkt. L.R. 17; N.V. Canoy Herfkens Steenfabrieken v. Poncelet, $60 \mathrm{La}$ jurisprudence commerciale de Bruxelles 277 (Tribunal de Commerce, Bruxelles 1967 ).

56. Spierkel v. Agence et Messageries de la Presse, S.A., 77 J.T. 459 (Cour d'Appel, Bruxelles I962), 3 Comm. Mkt. L.R. r42; ASPA v. Superbazars, 77 J.T. 298 (Tribunal de Commerce, Bruxelles I962), 2 Comm. Mkt. L.R. 28.

57. See note 9 suspra.

58. S.A. Association Générale des Fabricants Belges de Ciment Portland Artificiel v. S.A. Carrière Dufour, 79 J.T. 576 (Cour d'Appel, Bruxelles 1964), 4 Comm. Mkt. L.R. I93; N.V. Sieverding v. Vermeer-Thys, 29 R.W. col. 994 (Tribunal de première instance, Bruxelles I966).

59. Soc. dr. anglais Notek Electric Cy. v. Collignon, 82 J.T. 243 (Tribunal de première instance, Bruxelles I966). 
a problem admittedly raised by its unusual wording but tentatively answered affirmatively by the Commission ${ }^{60}$ and thus very much ready for an authoritative ruling by the Court of Justice. As two of the nine cases indicate, however, retention may be used to promote, as well as to avoid, Community standards. In these two cases the Belgian courts held the treaty antitrust rules violated ${ }^{61}$ in one of them this was, indeed, dispositive. ${ }^{62}$ Like the French, the Belgians have been reasonably friendly toward the obligation to suspend proceedings when the Commission initiates action in a case, even though suspension in judicial proceedings was a matter of treaty interpretation. ${ }^{63}$ Unlike at least some French courts, however, at least one Belgian court has done this in a way preserving the status quo, pending Commission action, against claims that the agreements should not be enforced in the interim. ${ }^{64}$

A German court recently certified to the Court of Justice a question concerning the compatibility with article 85 of a fine levied by the Federal Cartel Office under German antitrust law for a practice with "interstate" as well as "intrastate" characteristics. ${ }^{65}$ The effect of the certification was to delay the enforcement of the German law for the time being; in that sense, perhaps, it would be proper to classify the case with those in part I of this Article. On the other side of the ledger, however, appear at least I5 cases decided since 1962 in which certification could have been used and was not. Some were inappropriate for the additional procedure $;^{66}$ several were based upon a conservative definition of interstate commerce ${ }^{67}$ that the Court of Justice might not accept if asked; but most, including some in the Bun-

60. See, e.g., Commission decision of Oct. 22, 1964, 7 E.E.C. J.O. $276 \mathrm{I}$ (1964); Commission decision of July $30,1964,7$ E.E.C. J.O. 2287,3 Comm. Mkt. L.R. 505; Commission decision of Mar. II, 1964, E.E.C. J.O. 915,3 Comm. Mkt. I.R. 237. More recently a shift of attitude is discernible. See, e.g., Commission decision of Nov. 6, I968, in E.E.C. J.O. No. L 276/25 (1968).

6r. N.V. Union de Remorquage et de Sauvetage v. N.V. Schelde Sleepvaartbedrijf, 28 R.W. col. 3 I4 (Rechtbank van Koophandel, Antwerpen 1964), 4 Comm. Mkt. L.R. 25I; Blume v. Van Praag, 78 J.T. 733 (Rechtbank van Koophandel, Antwerpen 1962), 3 Comm. Mkt. L.R. 77.

62. N.V. Union de Remorquage et de Sauvetage v. N.V. Schelde Sleepvaartbedrijf, 28 R.W. col. 314 (Rechtbank van Koophandel, Antwerpen I964), 4 Comm. Mkt. L.R. 25 I.

63. See Buxbaum, supra note 7 , at $63-67$.

64. See, e.g., N.V. Sieverding v. Vermeer-Thys, 29 R.W. col. 994 (Tribunal de première instance, Bruxelles 1966); compare S.A. Association Générale des Fabricants Belges de Ciment Portland Artificiel v. S.A. Carrière Dufour, 79 J.T. 576 (Cour d'Appel, Bruxelles I964), 4 Comm. Mkt. L.R. x93. 65. Judgment of july $x 8,1968, x_{4}$ AWD 350 (Kammergericht (Berlin)). For its disposition by the Court of Justice see Farbenfabriken Bayer AG v. Bundeskartellamt, No. 14/68, Feb. 1969 (mimeo).

66. See, e.g., Judgment of Jan. 22, 1965, 15 WuW 588 (Landgericht, Mannheim), 4 Comm. Mkt. L.R. $23 x$.

67. This occurs frequently when a price-maintaining manufacturer enforces the nonsigner covenant and is met with the argument that these agreements inhibit interstate commerce. See, e.g., Judgment of Mar. 3I, I960, II WuW 555 (Oberlandesgericht, Frankfurt); Judgment of Oct. 2I, 1958, 9 WuW 298 (Oberlandesgericht, Düsseldorf); Judgment of Feb. 13, 1959, 1o WuW 639 (Landgericht, Frankfurt); unreported opinion in Laing v. Standard Electrik Lorenz AG (Landgericht, Mannheim, Apr. 15, 1966) summarized in Verzeichnis, stspra note 29, at 157-58.

For the impact of this type of clause on European enforcement policy see Mestmäcker, Die Wettbewerbsregeln des EWG-Vertrages im nationalen Recht, in WETTBEWERB ALS AUFGABE 567, $592 f f$ (a968). See also Ebb, The Grundig-Consten Case Revisited: Judicial Harmonization of National Law and Treaty Law in The Common Market, II5 U. PA. L. REv. 855, 88I (1967). 
desgerichtshof, ${ }^{68}$ avoided perfectly proper questions of interpretation through a variety of dubious devices. ${ }^{69}$ Finally, the German courts have not been willing to use the suspension procedure in favor of Commission action.

One particularly obstinate issue, and it is at the heart of the effort to preserve the national substantive regime, is the matter of expedited proceedings. It has become a commonplace doctrine with the German courts, ${ }^{70}$ and to some extent the Dutch, ${ }^{71}$ that certification is unavailable in a proceeding for interlocutory relief. American attorneys are familiar with the dispositive role of the temporary restraining order and the temporary injunction in resale-price-maintenance cases, and it should come as no surprise to learn that the same situation obtains elsewhere. The maverick dealer is temporarily enjoined from violating the nonsigner proviso, pending a plenary proceeding that never occurs. The sequence is prevalent enough in Germany to have become a matter of scholarly concern $;^{72}$ in time a more refined judicial attitude toward the practice may limit the tendency. In the meantime, however, it has all but blocked most efforts to certify the typical distribution case.

Another issue of some delicacy is the role of article 85 as an inroad on national industrial property laws. Much of the Grundig case ${ }^{73}$ involved the conflict between French trademark law and article 85, as the latter bore upon the right of the French holder of Grundig's international mark, Gint, to prevent imports of genuine Grundig products from Germany. Though

68. Judgment of Feb. 29, 1968, 49 Entscheidungen des Bundesgerichtshofs für Zivilsachen [hereinafter cited as BGHZ] 331, 7 Comm. Mkt. L.R. - - Judgment of June $14,1963,40$ BGHZ 135 (1963), 3 Comm. Mlt. L.R. 59. See, e.g., the critique of Steindorf, Zur Nichtigkeit Wettbewerbsbeschränkender Abreden im Europäischen Gemeinschaftsrecht, in ZUR INTEGRATION EUROPAs, FESTSCHRIFT Fün CARL FRIEDRICH OpHüLs 209 (W. Hallstein \&. H. Schlochauer eds. I965). For the analogous situation in Belgium see note 58 supra.

69. See, e.g., cases cited in note 68 supra; Judgment of Feb. 17 , 1966, I7 WuW 240 (Oberlandesgericht, München); Judgment of Sept. 21, 1965, 20 Betriebs-Berater 1164 (Oberlandesgericht, Nürnberg); Judgment of Jan. I7, I964, I4 WuW 535 (Oberlandesgericht, Hamm), 3 Comm. Mkt. L.R. 509; Judgment of Apr. 22, 1968, 18 WuW 69r (Landgericht, Dortmund); Judgment of Oct. 7, 1967, ${ }_{14}$ AWD 57 (Landgericht, Wiesbaden), noted in Johannes, Comment, [1968] GRUR-AIT 23; Judgment of Jan. 23, 1967, 14 AWD 58 (Landgericht, Hamburg); Judgment of Dec. 6, I960, II WuW 565 (Landgericht, Düsseldorf).

7o. See, e.g., Judgment of May 30, 1963, 13 WuW 626 (Oberlandesgericht, München), 3 Comm. Mkt. L.R. 87; Judgment of Mar. 3I, I960, IX WuW 555 (Oberlandesgericht, Frankfurt).

7r. See, e.g., Constructa Werke GmbH v. De Geus en Uitdenbogerd N.V., [1964] N.J. II2I (Hoge Raad), 4 Comm. Mkt. L.R. I7; Merck \& Co. v. Vyvyx N.V., [1966] N.J. 124 (ArrondissementsRechtbank, Rotterdam).

72. See F. Baur, Studien zum einstweiligen Rechtsschutz (1967). More specific discussions hereof in the context of article 177 include Paetow, Die "Vorabentscheidung" nach Art. 177 EWGVertrag, ihre formellen und materiellen Voratusetzunken, 2I MONATSSCHRIFT FÜR DeUTCHEs RECHT 445, 448 (1967), and Veegens, Comment, [1964] N.J. xi26. But see, e.g., the less concerned attitude of administrative law commentators, particularly Menger \& Erichsen, Höchstrichterliche Rechtsprechung zum Verwaltungsrecht, 57 Verwaltungsarchiv 64, 8I (I966); and Ule, supra note 7, at 6-8. See also Daig, supra note 7, at 294; Samkalden, Comment, 12 S.E.W. 267 (I964).

73. Etablissements Consten S.A.R.L. v. Commission de la C.E.E., 12 Rec. Jur. 429, 5 Comm. Mkt. L.R. 418 (I966). See, e.g., Wertheimer, National Trademark Law and the Common Market Rules of Competition, 4 Comm. Mkr. L. REv. 308, 399 (1967). 
the recent Parke, Davis decision of the Court of Justice ${ }^{\text {t4 }}$ suggested that mere unilateral exercise of a national patent right to bar infringing imports could not be converted into a forbidden collusive practice under article 85 , it was somewhat ambivalent on whether such an exercise could constitute abuse of a dominant position under article 86 . Nevertheless, only recently the German Bundesgerichtshof, in a case involving a plant patent, declined to certify this abuse question to the Court of Justice, on the ground that the seed-registration law governing the matter differed qualitatively from the patent law in an (unspecified) way, which prevented the exercise of rights thereunder from leading to the sort of conflict with articles 85 or 86 as might create an interpretation dispute. ${ }^{75}$ This kind of decision, while hardly predictive of results of other cases, does not augur well for expanding the role of the Court of Justice in deciding when the existence, enforcement, or abuse of a national statute conflicts with treaty provisions.

\section{ConCLUSION}

What can be gleaned from this cursory review of the implementation and use of article I77? The data are inherently too sketchy to justify pretentious speculations. Certainly they suggest some disappointment of overly optimistic expectations, and such disappointment has found some expression in the literature ${ }^{76}$ even if bemusement with the institution as such remains predominant. In the administrative-law field, where the hard work of achieving local cooperation with Luxembourg's pronouncements is not with the tribunals that seek those pronouncements but with the administrative agencies whose actions the certifying courts are there to control, the article I77 process has begun to take hold everywhere but in France. When one recalls that the Commission of the European Communities is an executive organ only, not a full-fledged bureaucracy, and that many of the national decisions attacked in these proceedings are Community orders merely farmed out to these national agencies for implementation, ${ }^{77}$ this progressive utilization of the certification procedure turns out to be less surprising and less significant.

74. See note 30 supra.

75. Judgment of Feb. 29, r968, 49 BGHZ 33I, 7 Comm. Mkt. L.R. —_- Judgment of June 20, I 668 , I4 AWD 390 (Landgericht, Düsseldorf). See also Judgment of Aug. 9, r967, [1968] GRURAIT 138 (Landgericht, Hamburg).

76. See, e.g., G. Prasch, Die unmittelbare Wirkung des EWG-Vertrages auf die WirtSChaftsunterneHMEN I49-52 (1967); Anthony, Comments on the Common Market, 41 Wash. L. REv. 423, 430 (I966); Constantinesco, supra note 7; Daig, supra note 7, at $287-89$.

77. See J. BouRrinet, Le pROBLEME AGRICOLE DANS L'INTÉGRATION EUROPÉnNE 220 (I964); V. Götz, Recht der Wirtschaftssubventronen r ro (1966); A. Spinelli, The Eurocrats (1966).

An interesting but only peripherally related matter is the debatable right of arbitration panels and less formal administrative agencies to use the certification procedure. For a reference to this area and a discussion of the political implications of allowing such certifications sce Gormley, The Future Role of Arbitration Within the EEC: The Right of an Arbitrator To Request a Preliminary Ruling Pursuant to Article I77, I2 ST. Lours U.L.J. 550 (1968). 
The only truly private law field so far subject to Community norms, antitrust, presents a far different picture. Here the federal "encroachment" is upon the interpretation and development of substantive legal doctrinethe essential tasks of the judiciary being asked to abet such encroachment -and is in its substance significantly at variance with the doctrines these courts have, at least so far, enunciated. This variance, explained by the recent and somewhat forced intrusion of antitrust doctrine in judicial traditions rather friendly to restrictive practices, ${ }^{78}$ is an unfortunate historical accident, and goes far to explain the relative failure of the certification process. It may be that it explains most of this failure, or timidity; when the Community norms happen to coincide with national law, a friendlier approach to certification might be expected. Ranged against this possibility, however, is the experience in France, where only a few courts even seemed to yield jurisdiction to the Commission in cases in which certification could be used to foster local antitrust policy.

An additional drawback of the current situation is its chilling effect upon uniform, not to mention vigorous, antitrust law enforcement. Five years ago, when I questioned the Commission's overeager assertion of essentially exclusive jurisdiction over Community antitrust enforcement activity (an assertion not envisaged in the original Treaty), ${ }^{79}$ it lacked the political base to exercise this competence and had not shown nor did it seem likely soon to be able to show a level of enforcement activity commensurate with its claims of competence. ${ }^{30}$ At the time it seemed preferable, always from the point of view of promoting vigorous antitrust enforcement, to try for the slower but perhaps more solidly based development of national administrative and judicial experience, competence, and vigor in this field. Such a buildup seemed worthwhile even without any great eagerness to use article I77, and despite the unsatisfactory nature of the Commission's right to intervene in proceedings under article $I 77,{ }^{81}$ which permits it only reaction, not action. And it still seems that had national agencies continued to process article 85 and 86 cases instead of accepting Brussels' interpretation of the implementing regulations, ${ }^{82}$ a substantial

78. See Riesenfeld, stupra note 44.

79. See Rome Treaty, art. 88; Reg. No. 17, art. 9, 5 E.E.C. J.O. 204 (1962), reprinted in I CCH CoMm. MRT. REP. I 2401 , at 1700 .

80. Buxbaum, supra note 7, at 57-58, 94 .

This is not the place to discuss the subsequent history of the Commission's enforcement activity and particularly its acquiescence in the "European size" trend in horizontal agreements and fusions. I would, however, at least point to Miarkert's comment that present European policies in this regard constitute "a kited check against the future." Markert, Die Richtlinien des amerikanischen Justizministeriums für die Behandlung von Unternehmenszusammenschlïssen ("Merger Guidelines"), I4 AWD 377, 38r (r968).

8I. Protocol on the Statute of the Court of Justice of the European Economic Community, art. 20, executed concurrently with the Rome Treaty, 298 U.N.T.S. x48. See Buxbaum, supra note 7 , at 75.

82. See the cryptic comment in Deutscher Bundestag, Drucksache V/530, Bericht des Bundeskartellamtes über seine Tätigkeit im Jahre 1965 sowie ïber Lage und Entwicklung auf seinem Auf- 
body of case law would have been generated nationally, even, perhaps, in time affecting judicial attitudes toward article I77. Because at present national courts must deal with the least attractive aspects of antitrust activitythe use of antitrust doctrines as challenges to traditional notions of fair competition in private actions - and thus have become predictably unfriendly to Community antitrust philosophy, they have been reluctant to certify these questions to the Court of Justice. That reluctance is doubly unfortunate: The opportunity to fashion questionable legal doctrines is only too apparent; at the same time the Commission has little opportunity to do anything about the trend, since it lacks power to intervene in this private litigation absent a certification.

Whether the key to judicial resistance to article $I_{77}$ has been substantive conflict between applicable doctrines or outright political opposition to federalization, discouraging use of the procedure even where there is substantive harmony, the lesson of the Community to date seems to be that other mechanisms for getting questions before the regional judicial body might be more productive than article 177 certification. One of the most useful might be patterned after the United States Supreme Court's certiorari procedure, allowing either of the parties to invoke the jurisdiction of the central court. Certification of the interpretation problem at issue would no longer be dependent on the discretion, complete or partial, of the originally seized court; ${ }^{83}$ instead, it would rest with the certifying party. Perhaps a flood of certifications, even a flood of trivial certifications, would be the consequence. It does seem that only a party interested in and able to afford dilatory tactics would find this gambit worth the cost; nevertheless, exactly in the kind of antitrust litigation previously discussed this would be a real risk. If this proved to be the experience, and perhaps even from the outset, a discretionary power in the regional courts to reject the request might be appropriate. This could be joined to something like our well-known certificate of probable cause ${ }^{84}$ or, indeed, to something resembling the present article 177 : If the originally seized court certifies the question the regional court must take it, otherwise it may. At the beginning of an effort at federalization, maximum opportunity to certify questions might well be valuable enough to this essentially political process to over-

gabengebiet, Apr. 21, 1966, at 69-70; it has been repeated in subsequent years. The significance of this self-restraint can be gleaned from id., Drucksache IV/2370 ( 1963 Report), at 46 ; see Buxbaum, stupra note 7 , at 67 n.56; for an example of its effects upon the developing case law see, e.g., Decision of Nov. I4, I963, I4 WuW 437 (Bundeskartellamt).

83. See Riese, Über den Rechtsschutz der Privatpersonen und Unternehmen in der europäischen Wirtschaftsgemeinschaft, in PROBLEME DES EUROPÄISCHEN RECHTS, FestschrIfT Für WALTER HALLSTEIN 414,429 (1966). See also the review of this problem and the related one of the Court of Justice's right to grant review sua sponte, in Mok, Should the "first paragraph" of art. I77 of the E.E.C. Treaty be read as a separate clause?, 6 Comm. MKT. L. Rev. 548 (I968). The position of the Court of Justice on this issue is reviewed in Schlochauer, stspra note 19 , at $445-46$.

84. See note 5 supra and accompanying text. 
ride the fear of excessive use. ${ }^{85}$ Thus the self-interest of litigants could be harnessed to the political goal of creating a communal loyalty. ${ }^{86}$ In a limited sense-limited because of the contrast between the EEC's highly developed economic and social structure and our early beginnings-these questions and values were reflected in the shift of the United States Supreme Court's own jurisdictional framework from mandatory appellate and certiorari jurisdiction to the discretionary jurisdiction required by the pressure of a docket reflecting an increasingly complex society. ${ }^{87} \mathrm{All}$ in all, a variety of procedures can be devised and controlled that would encourage wider use of this federalizing device whenever a polity not yet ready for full appellate control of a national judicial system or for a system of inferior federal courts might wish to adopt or adapt the European experiment.

The most important lesson, however, may be merely that of the time span involved in achieving the voluntary assimilation of a supranational court into a national judicial structure. ${ }^{88}$ Only a decade has elapsed since the experiment started. Early enthusiasm has faded as national political values have reasserted themselves, but the institutional framework has been introduced and is continuing to work. Perhaps no more is involved than was expressed long ago by Mayor Adler, speaking of pressures to rezone Rochester's East Avenue: The time for the inevitable has not yet arrived.*

85. See Schlochauer, supra note 19.

86. See S. ScheingoLd, supra note 6 , at $285 \mathrm{ff}$.

87. This development was confirmed by the "Judges Bill" of 1925. Act of Feb. 13, I925, ch. 229, 43 Stat. 936 . See also Act of Sept. 6, 19x6, ch. $448, \S 2,39$ Stat. 726 . For a thorough discussion of the Supreme Court's certiorari practice see R. Stern \& E. Gressman, Supreme Court Practice ix7-6y (3d ed. 1962).

88. For larger-scale discussions of both the normative role played by legal institutions and "the law" in the integration process and the political limitations constricting that role see S. SCHEINGoLD, supra note 6. See also H. WAGNER, GRUNDBEGRIFFe des BeschlussRECHTS DER EtJROPÄTSCHEN GEMEINSCHAFTEN I- $18,243-56$ (I965).

* The type for this Article was set before the appearance of Hay, Supremacy of Community Law in National Cotrts, 16 AMr. J. Comp. I. 524 (I968). The two may be profitably read in conjunction, particularly in view of Hay's emphasis on the administrative cases. 